\title{
COMPETITIVENESS OF POLISH AND GERMAN FARMS SPECIALIZED IN FIELD CROPS
}

\author{
Marek Zieliński ${ }^{1}$, Wojciech Ziętara ${ }^{1 \bowtie}$ \\ ${ }^{1}$ Institute of Agriculture and Food Economics - National Research Institute, Poland
}

\begin{abstract}
This paper presents the competitiveness of Polish and German farms specialized in field crops. The competitiveness index, as adopted from W. Kleinhanss, was used for that purpose. It represents the relation between farm income and costs of own productive inputs. The competitiveness of farms analyzed was assessed in three periods: 2006-2008, 2010-2012 and 2014-2016, based on agricultural accounting data of the European FADN. The economic size of farms was expressed in ESU in the first period and in thousand EUR of standard output (SO) in the second and third period. The study showed that Polish farms in corresponding economic size classes exhibited a higher competitive capacity. They had a larger utilized agricultural area (UAA), a lower value of assets per hectare of UAA and per AWU and a lower level of production intensity. Also, they were less dependent on all types of subsidies. In Polish farms, the organization of production - expressed as the share of cereals in utilized agricultural area - was less sustainable.
\end{abstract}

Keywords: competitiveness, farms specialized in field crops, Polish farms, German farms

\section{INTRODUCTION}

Just like other sections of national economy, agriculture experiences production specialization and concentration processes. This is evidenced by a growing share of farms specializing in specific production types in the total number of farms and in the operation of utilized agricultural area (UAA) ${ }^{1}$. Note that these processes are reflected in Polish and German agriculture, for instance through a significant share of farms specializing in field crops $^{2}$. In 2010 and 2016, the share of those farms in the total number of farms in Poland was $52 \%$ and $56.5 \%$, respectively. The corresponding ratios for Germany are lower (24.5\% and 30.5\%, see Table 1). In Poland, those farms operated $31.4 \%$ and $52.5 \%$ of UAA, respectively, while in Germany the corresponding ratios were $30.9 \%$ and $36.1 \%$. The above means that this type of farms plays a significant and constantly growing role in agriculture, especially in Poland.

Farms specialized in field crops include two subtypes: farms specializing in the cultivation of cereals, oilseeds and protein crops (type A) and in the cultivation of

\footnotetext{
${ }^{1}$ Note that this is because in the last few decades, there has been an increase in the impact of "diversifying" forces that are seated in the market and make farm specialize and concentrate the production. According to T. Brinkmann, agriculture is, in fact, affected by two groups of forces, namely the "diversifying" and "integrating" forces. The diversifying forces are found in the farm's surroundings, mainly in the market, and make farms specialize and concentrate their production. In turn, the "integrating" forces are within the farm and make farms engage in multilateral production by bringing to the fore a more efficient use of productive inputs through the use of internal relations and dependencies (Brinkmann, 1922).

${ }^{2}$ According to the typology of farms based on the FADN methodology.
}

$\bowtie$ Prof. Wojciech Ziętara, PhD hab., Institute of Agricultural and Food Economics - National Research Institute, Świętokrzyska 20 St., 00-002 Warsaw, Poland, e-mail: zietrara@ierigz.waw.pl, https://orcid.org/0000-0002-1990-6342 
Zieliński, M., Ziętara, W. (2019). Competitiveness of Polish and German farms specialized in field crops. J. Agribus. Rural Dev., 3(53), 281-290. http://dx.doi.org/10.17306/J.JARD.2019.01261

Table 1. Number and structure of farms specialized in field crops in Poland and Germany

\begin{tabular}{|c|c|c|c|c|c|c|c|c|}
\hline \multirow{3}{*}{ Specification } & \multicolumn{4}{|c|}{ Germany } & \multicolumn{4}{|c|}{ Poland } \\
\hline & \multicolumn{2}{|c|}{2010} & \multicolumn{2}{|c|}{2016} & \multicolumn{2}{|c|}{2010} & \multicolumn{2}{|c|}{2016} \\
\hline & $\begin{array}{l}\text { number } \\
\text { (thous.) }\end{array}$ & $(\%)$ & $\begin{array}{l}\text { number } \\
\text { (thous.) }\end{array}$ & $(\%)$ & $\begin{array}{l}\text { number } \\
\text { (thous.) }\end{array}$ & $(\%)$ & $\begin{array}{l}\text { number } \\
\text { (thous.) }\end{array}$ & $(\%)$ \\
\hline Type A farms & 35.60 & 47.00 & 39.80 & 47.40 & 658.85 & 87.00 & 450.53 & 56.50 \\
\hline Type B farms & 37.70 & 53.00 & 44.10 & 52.60 & 98.60 & 13.00 & 346.88 & 43.50 \\
\hline All farms with field crops & 73.30 & 100.00 & 83.90 & 100.00 & 757.45 & 100.00 & 797.41 & 100.00 \\
\hline $\begin{array}{l}\text { Share of farms with field crops } \\
\text { in the total number of farms }(\%)\end{array}$ & \multicolumn{2}{|c|}{24.50} & \multicolumn{2}{|c|}{30.50} & \multicolumn{2}{|c|}{52.00} & \multicolumn{2}{|c|}{56.50} \\
\hline $\begin{array}{l}\text { Share of farms with field crops } \\
\text { in utilized agricultural area (\%) }\end{array}$ & \multicolumn{2}{|c|}{30.90} & \multicolumn{2}{|c|}{36.10} & \multicolumn{2}{|c|}{31.40} & \multicolumn{2}{|c|}{52.50} \\
\hline Share of cereals in the sown area $(\%)$ & \multicolumn{2}{|c|}{55.7} & \multicolumn{2}{|c|}{53.8} & \multicolumn{2}{|c|}{70.4} & \multicolumn{2}{|c|}{69.80} \\
\hline
\end{tabular}

Source: CSO, 2015; 2018; Statistisches..., 2014; 2017.

various crops (type B) $)^{3,4}$. In Polish farms, type A clearly predominated, with a share of $87 \%$ and $56.5 \%{ }^{5}$ in 2010 and 2016, respectively. In Germany, it was ca. $47 \%$ in both years. There were also differences in the production structure, expressed by the share of cereals in the sown area. In Polish farms specializing in cereals, oilseeds and protein crops, the share of cereals was ca. $70 \%$, while in German farms it was $55.5 \%$ and $53.8 \%$. Note that the high share of cereals (above 66\%) poses a risk of depleting the level of organic matter in soil. From this point of view, the sowing mix in German farms is more sustainable.

Having in mind the increasingly large importance of farms specialized in field crops (and in particular in the cultivation of cereals, oilseeds and protein crops), it is reasonable to examine their organization, the level of production intensity, and their production and economic performance, and to determine their competitiveness and development prospects.

\footnotetext{
${ }^{3}$ In the FADN typology, these types of farms are designated as Type 15 and 16. For the sake of simplicity, A and B designations are used in this analysis.

${ }^{4}$ Applies to the cultivation of various crops, including cereals, oilseeds, legumes for seeds, fodder crops, industrial crops (exclusive of oilseeds) and root crops.

${ }^{5}$ The share of type A went down in 2016 because that year, mixed farms with various crops (which increased the number and share of type B farms) were included in the group of farms with field crops.
}

\section{OBJECTIVE AND METHOD OF THE STUDIES}

The objective of this paper was to assess the competitiveness of the abovementioned subtypes of farms in Poland and Germany and its determinants. It is reasonable to compare Polish and German farms as they operate under similar climate conditions. The study focused on Polish and German farms covered by the European FADN in three study periods: 2006-2008, 2010-2012 and 2014-2016. The averages of the selected characteristics were calculated for each period. This was reasonable as it eliminated fluctuations in the size of characteristics during these periods, even though they were small as they did not exceed a few percent ${ }^{6} .2009$ and 2013 were not covered by this study. In the first period, the analysis covered farms of the top three classes

\footnotetext{
${ }^{6}$ This study did not examine the statistical significance of differences between the identified subgroups of Polish and German farms. This is because the values of variables in the European FADN are provided only as average figures for a group of farms, and their distribution is unavailable. Therefore, it was impossible to use the statistical tests of significance of differences, whether parametric (Student's t-test or Cochran-Cox test) or non-parametric (e.g. Mann-Whitney U test). However, note that the differences between individual values of variables in the groups of Polish and German farms, as determined in this paper, proved to be generally evident. This suggests that these differences are likely to be statistically significant.
} 
of economic size expressed in ESU 7 : 16-40; 40-100 and $\geq 100$ ESU. On the other hand, in the second and third period, the study covered farms from the top four economic size classes in terms of standard output (SO) value $^{8}$ : EUR $25-50$ thousand; EUR 50-100 thousand; EUR $100-500$ thousand and $\geq$ EUR 500 thousand. It should be added that since 2010, the economic size of farms in the European FADN has been expressed in SO instead of ESU. Smaller farms were not included in the study as they were not covered by the German FADN. Moreover, as shown in previous studies, these farms were uncompetitive (Ziętara and Zieliński, 2012; 2015).

The authors' intention was to determine the level of competitiveness in the groups of Polish and German farms covered by this analysis. It was found that in order to be competitive, a farm must generate enough income to fully pay for its own productive inputs and enable further development. In order to determine the farms' level of competitiveness, this study relied on the Competitiveness Index (Wk), as used by W. Kleinhanss (2015). The Index is structurally based on the competitiveness measurement concept proposed by Gallardo et al. (2001). Note also that the Index has been increasingly used in the Polish economic and agricultural literature. In this context, in addition to analyses carried out by the authors of this paper, mention should also be made of other studies, including Płonka (2015) who used the Competitiveness Index in determining the competitiveness level of farms owned by natural persons who kept agricultural accounts for the Polish FADN in 2005-2013 on a continuous basis, and Sass (2017) who used it in assessing the efficiency and competitiveness in function of the production scale of dairy farms in Wielkopolska and Śląsk.

The Competitiveness Index (quotient) was determined as the ratio of farm income (Dzgr) to total estimated costs of own productive inputs: labor, land and

\footnotetext{
${ }^{7}$ ESU (European Size Unit) a European measure of farm size equivalent to a gross margin of EUR 1,200. Six economic size classes of farms were identified based on this criterion: I: very small $(<4$ ESU); II: small $(4 \leq$ ESU $<8)$; III: medium-small ( $8 \leq$ ESU < 16); IV: medium-large $(16 \leq$ ESU < 40); V: large $(40 \leq$ ESU $<100)$ and VI: very large $(\leq 100$ ESU).

${ }^{8}$ SO: Standard Output value expressed in thousand EUR. SO is the basis for identifying 6 corresponding economic size classes with the following intervals: very small $(2 \leq \mathrm{SO}<8)$; small $(8 \leq$ $\mathrm{SO}<25)$; medium-small $(25 \leq \mathrm{SO}<50)$; medium-large $(50 \leq \mathrm{SO}$ $<100)$; large $(100 \leq \mathrm{SO}<500)$ and very large $(\leq 500)$.
}

capital (Equation 1) ${ }^{9}$. The Wk classification was adopted based on a study by Kleinhanss. The following classes were identified: Wk (-): if Dzgr is negative $\left(\mathrm{Wk}_{1}\right)$; $0<\mathrm{Wk}<1$ : costs of own productive inputs are partially covered $\left(\mathrm{Wk}_{2}\right) ; 1 \leq \mathrm{wk}<2:-$ costs of own productive inputs are fully covered $\left(\mathrm{Wk}_{3}\right), \mathrm{Wk} \geq 2$ : costs of own productive inputs are covered more than twice $\left(\mathrm{Wk}_{4}\right)$. $\mathrm{Wk}_{3}$ evidences the competitive capacity of farms while $\mathrm{Wk}_{4}$ means they are fully competitive. This is convergent with Biswanger (2011) who stated that in order for a company to develop, its profit margin should be twice the loan interest rate.

$$
\mathrm{Wk}=\frac{\mathrm{Dzgr}}{\mathrm{Kwz}+\mathrm{Kwp}+\mathrm{Kwk}}
$$

where:

Wk - Competitiveness Index

Dzgr - farm income

KwZ - alternative cost of own land

Kwp - alternative cost of own labor

Kwk - alternative cost of own capital (exclusive of own land)

In this paper, competitiveness was defined as the farm's ability to develop. This is achieved if farm income covers twice the costs of own productive inputs. That approach differs from the traditional definition which sees competitiveness as an advantage (in terms of costs, prices, quality etc.) over competitors. Previously, the authors determined the competitive capacity of farms based on "entrepreneur's profit"10 (Ziętara and Zieliński, 2015). There was a doubt whether that approach was appropriate. Farms from different countries do not compete directly in the EU and global market; trading companies do so. Therefore, determining the competitiveness of farms as their ability to develop under national market conditions seems to be a wellfounded approach.

${ }^{9}$ The cost of the farmer's and his family's own labor was set at a level of the cost of hired labor in the corresponding economic size classes. The cost of using own land was set at a level of land rent in the corresponding economic size classes. The cost of own capital was set at a level of the interest rate of long-term government bonds.

${ }^{10}$ The entrepreneur's profit was calculated as the difference between farm income and alternative cost of using its own productive inputs (labor, land and capital) (Ziętara and Zieliński, 2015). 


\section{COMPETITIVENESS OF POLISH AND GERMAN FARMS IN 2006-2008}

The figures in Table 2 show that in the study period, Polish farms (of all economic size classes) specializing in cereals, oilseeds and protein crops (type A) achieved the "entrepreneur's profit" with a Competitiveness Index of 1.31 to 1.59 , reflecting their competitive capacity. They also recorded a positive net investment rate. In Germany, medium-large (16-40 ESU) and large (40-100 ESU) type A farms failed to achieve this category of profit, and recorded Competition Indexes of 0.25 and 0.77, respectively, reflecting the absence of competitive capacity. Only very large farms ( $\geq 100$ ESU) achieved the competitive capacity status in this type. The analysis of Competitiveness Indexes in type B farms indicates that medium-large and very large Polish farms exhibited their competitive capacity whereas large farms were fully competitive with a $\mathrm{Wk}_{4}$ of 2.12. Among German type B farms, only large and very large farms demonstrated their competitive capacity. Conversely, it was not the case for medium-large farms. Based on the analysis, it can be summarized that achieving the entrepreneur's profit is indicative of the farms' competitive capacity but does provide grounds for concluding that they are fully competitive.

The question arises about the characteristics of competitive farms and of those with a competitive capacity. The figures in Table 3 show that fully competitiveness was exhibited by Polish type B farms which operated 114.9 ha of utilized agricultural area, on average. In their case, the value of assets per hectare of UAA and per AWU was about 3 times smaller than in German farms of the same economic size class. The level of production intensity, the cost of external inputs and the share of subsidies in income were lower in those farms. In Polish farms, it was $52.4 \%$ vs. $74.6 \%$ in German farms.

German farms that proved to be unable to develop (as evidenced by a value of the $\mathrm{WK}_{2}$ index below 1) do not exhibit any special features allowing to indicate the reasons for this situation. They do not differ substantially from other farms in their utilized agricultural area, value of assets per hectare and per AWU or levels of production intensity. The reason for their non-competitiveness can be believed to be mismanagement.

Table 2. Selected variables describing the competitive capacity of Polish and German farms specializing in the cultivation of cereals, oilseeds and protein crops for seeds (type A) and in the cultivation of various crops (type B), grouped by economic size (in ESU) in 2006-2008

\begin{tabular}{|c|c|c|c|c|c|c|c|}
\hline \multirow{3}{*}{ Specification } & \multirow{3}{*}{$\begin{array}{l}\text { Farm } \\
\text { type }\end{array}$} & \multicolumn{6}{|c|}{ Farm size (ESU) } \\
\hline & & \multicolumn{2}{|c|}{$16-40$} & \multicolumn{2}{|c|}{$40-100$} & \multicolumn{2}{|c|}{$>100$} \\
\hline & & Poland & Germany & Poland & Germany & Poland & Germany \\
\hline \multirow{2}{*}{$\begin{array}{l}\text { Farm income } \\
\text { (EUR thous./farm) }\end{array}$} & A & 29.20 & 7.85 & 70.30 & 34.44 & 117.44 & 115.45 \\
\hline & $\mathrm{B}$ & 30.06 & 19.55 & 57.45 & 46.56 & 111.04 & 98.56 \\
\hline \multirow{2}{*}{$\begin{array}{l}\text { Costs of own productive inputs } \\
\text { (EUR thous./farm) }\end{array}$} & A & 20.73 & 30.80 & 53.78 & 44.74 & 73.93 & 70.07 \\
\hline & $\mathrm{B}$ & 18.41 & 27.43 & 27.04 & 41.75 & 91.07 & 58.25 \\
\hline \multirow{2}{*}{$\begin{array}{l}\text { Entrepreneur's profit } \\
\text { (EUR thous./farm) }\end{array}$} & A & 8.47 & -22.95 & 16.52 & -10.30 & 43.51 & 45.38 \\
\hline & $\mathrm{B}$ & 11.65 & -7.88 & 30.41 & 4.81 & 19.97 & 40.31 \\
\hline \multirow[t]{2}{*}{ Competitiveness Index (ratio) } & A & 1.41 & 0.25 & 1.31 & 0.77 & 1.59 & 1.65 \\
\hline & $\mathrm{B}$ & 1.63 & 0.71 & 2.12 & 1.16 & 1.22 & 1.69 \\
\hline \multirow{2}{*}{$\begin{array}{l}\text { Net investment rate } \\
(\%)\end{array}$} & $\mathrm{A}$ & 83.3 & -8.2 & 108.6 & 65.8 & 151.9 & 44.4 \\
\hline & B & 77.3 & 39.5 & 120.3 & 62.2 & 40.1 & 58.7 \\
\hline
\end{tabular}

Source: own study based on European FADN. 
Zieliński, M., Ziętara, W. (2019). Competitiveness of Polish and German farms specialized in field crops. J. Agribus. Rural Dev., 3(53), 281-290. http://dx.doi.org/10.17306/J.JARD.2019.01261

Table 3. Selected variables of Polish and German farms specializing in the cultivation of cereals, oilseeds and protein crops for seeds (type A) and in the cultivation of various crops (type B), grouped by economic size (ESU) in 2006-2008

\begin{tabular}{|c|c|c|c|c|c|c|c|}
\hline \multirow{3}{*}{ Specification } & \multirow{3}{*}{$\begin{array}{l}\text { Farm } \\
\text { type }\end{array}$} & \multicolumn{6}{|c|}{ Farms size (ESU) } \\
\hline & & \multicolumn{2}{|c|}{$16-40$} & \multicolumn{2}{|c|}{$40-100$} & \multicolumn{2}{|c|}{$>100$} \\
\hline & & Poland & Germany & Poland & Germany & Poland & Germany \\
\hline \multirow[t]{2}{*}{ Utilized agricultural area (ha) } & A & 93.3 & 57.3 & 223.9 & 133.5 & 793.5 & 552.4 \\
\hline & $\mathrm{B}$ & 50.1 & 39.1 & 114.9 & 77.6 & 555.2 & 246.4 \\
\hline \multirow{2}{*}{$\begin{array}{l}\text { Value of assets per hectare } \\
\text { of UAA (EUR thous./ha) }\end{array}$} & A & 2.47 & 11.56 & 2.10 & 6.48 & 2.12 & 3.20 \\
\hline & B & 3.90 & 15.00 & 3.20 & 13.40 & 2.40 & 6.30 \\
\hline \multirow{2}{*}{$\begin{array}{l}\text { Value of assets } \\
\text { (EUR thous./AWU) }\end{array}$} & A & 126.42 & 537.93 & 159.41 & 558.61 & 165.07 & 368.46 \\
\hline & $\mathrm{B}$ & 72.50 & 442.40 & 119.00 & 590.80 & 109.50 & 360.50 \\
\hline \multirow{2}{*}{$\begin{array}{l}\text { Share of cereals in UAA } \\
(\%)\end{array}$} & A & 74.10 & 61.80 & 73.73 & 62.53 & 67.50 & 60.37 \\
\hline & $\mathrm{B}$ & 54.60 & 52.10 & 56.40 & 54.20 & 54.00 & 48.10 \\
\hline \multirow{2}{*}{$\begin{array}{l}\text { Total costs of UAA } \\
\text { (EUR thous./ha) }\end{array}$} & A & 0.58 & 1.25 & 0.61 & 1.21 & 0.83 & 1.27 \\
\hline & B & 0.92 & 1.74 & 0.86 & 1.83 & 1.12 & 2.01 \\
\hline \multirow{2}{*}{$\begin{array}{l}\text { Direct costs of UAA } \\
\text { (EUR thous./ha) }\end{array}$} & A & 0.29 & 0.37 & 0.31 & 0.44 & 0.37 & 0.44 \\
\hline & B & 0.44 & 0.49 & 0.43 & 0.62 & 0.48 & 0.70 \\
\hline \multirow{2}{*}{$\begin{array}{l}\text { Costs of external inputs } \\
\text { (EUR thous./ha) }\end{array}$} & A & 0.04 & 0.16 & 0.06 & 0.19 & 0.15 & 0.35 \\
\hline & B & 0.10 & 0.25 & 0.08 & 0.30 & 0.23 & 0.51 \\
\hline \multirow{2}{*}{$\begin{array}{l}\text { Share of subsidies in farm } \\
\text { income }(\%)\end{array}$} & A & 71.00 & 277.70 & 73.10 & 137.50 & 244.60 & 15.40 \\
\hline & B & 45.90 & 106.80 & 52.40 & 74.60 & 148.90 & 83.20 \\
\hline
\end{tabular}

Source: own study based on European FADN.

Regardless of the differences in the Competitiveness Index, it was concluded that Polish farms able to compete with German farms had the following characteristics:

- They had a higher farm income. Larger differences in favor of Polish farms were found in type A, especially in the medium-large class where the difference was $271 \%$.

- In the medium-large class, they incurred lower costs (by ca. $32 \%$ ) of own productive inputs. In further classes, the relations were different, except for large type B farms.

- They operated a larger utilized agricultural area. In type A, the difference was between $46 \%$ and $67 \%$, whereas in type B it varied in the range of $28 \%$ to $125 \%$,

- They had a significantly lower value of assets, both per hectare of UAA and per AWU.
- They had a less sustainable sowing mix, especially in type A.

- Their level of production intensity, determined by total costs per hectare of UAA, was lower by ca. $50 \%$. The differences in direct costs were considerably lower (between $16 \%$ and $31 \%$ ).

- They reported lower costs of external inputs, especially in lower economic size classes.

- They had a smaller share of subsidies in farm income, except for the class of above 100 ESU where the share of subsidies in both types of Polish farms was higher and amounted to $244 \%$ and $149 \%$, respectively. The corresponding ratios for German farms were $15 \%$ and $83 \%$. 


\section{COMPETITIVENESS OF POLISH AND GERMAN FARMS IN 2010-2012}

The competitiveness of farms specializing in field crops has clearly increased in 2010-2012 compared to the previous period. This is evidenced by figures provided in Tables 4 and 5. All Polish farms earned the entrepreneur's profit. Competitive capacity was exhibited by medium-small type A and type B farms and very large type B farms. In turn, Polish medium-large and large type A and type B farms and very large type A farms were fully competitive. Conversely, German mediumsmall type A and type B farms and medium-large type A farms did not demonstrate their competitive capacity. Competitive capacity was found in medium-large type B farms and in large type A farms; large type B farms and very large type A and type B farms were fully competitive.

When comparing Polish and German farms specializing in field crops in 2010-2012, it can be concluded that Polish farms:

- had higher farm incomes, except for very large type B farms,
- had lower costs of own productive inputs, except for type B farms in the largest economic size class where it was the opposite,

- had a larger UAA, except for medium-small type B farms; in addition, the area of type B farms was smaller in all economic size classes,

- had a lower value of assets per hectare of UAA and per AWU; larger differences in favor of German farms were found in smaller farms,

- had a less sustainable production structure, defined by the share of cereals in utilized agricultural area; the share of cereals varied in the range of $67 \%$ to $71 \%$ in Polish type A farms, and in the range of $61 \%$ to $66 \%$ in German farms; the share of cereals in type B was by several percent lower,

- had a production intensity lower by ca. $50 \%$ on average; the difference in direct costs was smaller,

- incurred lower costs of external inputs, especially in economically smaller farms,

- had a lower share of subsidies in farm income, varying in the range of $57 \%$ to $82 \%$ in type A farms, and in the range of $182 \%$ and $145 \%$ in German farms; similar patterns were found in type B farms; however, the share of subsidies in farm income was lower,

Table 4. Selected variables describing the competitive capacity of Polish and German farms specializing in the cultivation of cereals, oilseeds and protein crops for seeds (type A) and in the cultivation of various crops (type B), grouped by economic size (SO) in 2010-2012

\begin{tabular}{|c|c|c|c|c|c|c|c|c|c|}
\hline \multirow{3}{*}{ Specification } & \multirow{3}{*}{$\begin{array}{l}\text { Farm } \\
\text { type }\end{array}$} & \multicolumn{8}{|c|}{ Farms by SO (EUR thous.) } \\
\hline & & \multicolumn{2}{|c|}{$25-50$} & \multicolumn{2}{|c|}{$50-100$} & \multicolumn{2}{|c|}{$100-500$} & \multicolumn{2}{|c|}{$\geq 500$} \\
\hline & & Poland & Germany & Poland & Germany & Poland & Germany & Poland & Germany \\
\hline \multirow{2}{*}{$\begin{array}{l}\text { Farm income } \\
\text { (EUR thous./farm) }\end{array}$} & A & 29.22 & 9.05 & 56.43 & 27.55 & 135.95 & 82.99 & 390.56 & 291.86 \\
\hline & B & 23.75 & 15.51 & 40.89 & 33.92 & 93.95 & 81.10 & 138.49 & 196.89 \\
\hline \multirow{2}{*}{$\begin{array}{l}\text { Costs of own productive inputs } \\
\text { (EUR thous./farm) }\end{array}$} & A & 15.63 & 18.47 & 22.48 & 32.03 & 47.04 & 57.63 & 99.13 & 113.12 \\
\hline & $\mathrm{B}$ & 14.57 & 20.41 & 20.24 & 27.58 & 36.13 & 37.37 & 112.59 & 70.32 \\
\hline \multirow{2}{*}{$\begin{array}{l}\text { Entrepreneur's profit } \\
\text { (EUR thous./farm) }\end{array}$} & A & 13.52 & -9.42 & 33.95 & -4.48 & 88.91 & 25.36 & 291.43 & 174.84 \\
\hline & B & 9.18 & -4.9 & 20.65 & 6.34 & 57.82 & 43.73 & 25.90 & 126.57 \\
\hline \multirow[t]{2}{*}{ Competitiveness Index (ratio) } & A & 1.87 & 0.49 & 2.51 & 0.86 & 2.89 & 1.44 & 3.94 & 2.58 \\
\hline & B & 1.63 & 0.76 & 2.02 & 1.23 & 2.60 & 2.17 & 1.23 & 2.80 \\
\hline \multirow[t]{2}{*}{ Net investment rate $(\%)$} & A & 57.72 & 4.49 & 126.33 & 24.08 & 145.25 & 38.86 & 107.51 & 115.52 \\
\hline & B & 50.16 & 10.28 & 101.63 & 191.23 & 80.81 & 47.97 & 94.12 & 59.24 \\
\hline
\end{tabular}

Source: own study based on FADN data. 
Zieliński, M., Ziętara, W. (2019). Competitiveness of Polish and German farms specialized in field crops. J. Agribus. Rural Dev., 3(53), 281-290. http://dx.doi.org/10.17306/J.JARD.2019.01261

Table 5. Selected variables of Polish and German farms specializing in the cultivation of cereals, oilseeds and protein crops for seeds (type A) and in the cultivation of various crops (type B), grouped by economic size (SO) in 2010-2012

\begin{tabular}{|c|c|c|c|c|c|c|c|c|c|}
\hline \multirow{3}{*}{ Specification } & \multirow{3}{*}{$\begin{array}{l}\text { Farm } \\
\text { type }\end{array}$} & \multicolumn{8}{|c|}{ Farms by SO (EUR thous.) } \\
\hline & & \multicolumn{2}{|c|}{$25-50$} & \multicolumn{2}{|c|}{$50-100$} & \multicolumn{2}{|c|}{$100-500$} & \multicolumn{2}{|c|}{$\geq 500$} \\
\hline & & Poland & Germany & Poland & Germany & Poland & Germany & Poland & Germany \\
\hline \multirow[t]{2}{*}{ Utilized agricultural area (ha) } & A & 59.38 & 40.38 & 109.57 & 75.70 & 318.57 & 219.29 & $1,271.54$ & $1,035.35$ \\
\hline & B & 34.23 & 36.63 & 67.41 & 63.77 & 153.18 & 110.75 & $1,001.62$ & 390.71 \\
\hline \multirow{2}{*}{$\begin{array}{l}\text { Value of assets per hectare of UAA } \\
\text { (EUR thous./ha) }\end{array}$} & A & 5.71 & 11.31 & 5.55 & 10.13 & 4.01 & 4.97 & 2.27 & 3.45 \\
\hline & $\mathrm{B}$ & 7.86 & 14.28 & 7.34 & 12.37 & 6.32 & 10.99 & 3.46 & 6.44 \\
\hline \multirow{2}{*}{$\begin{array}{l}\text { Value of assets } \\
\text { (EUR thous./AWU) }\end{array}$} & A & 210.59 & 485.71 & 314.74 & 635.50 & 266.57 & 547.92 & 129.16 & 430.12 \\
\hline & $\mathrm{B}$ & 113.20 & 529.89 & 199.14 & 622.65 & 217.21 & 583.49 & 119.71 & 307.18 \\
\hline \multirow{2}{*}{$\begin{array}{l}\text { Share of cereals in UAA } \\
(\%)\end{array}$} & A & 71.36 & 65.77 & 67.97 & 64.45 & 67.97 & 64.45 & 67.17 & 60.92 \\
\hline & B & 53.30 & 43.96 & 55.62 & 47.29 & 50.14 & 48.33 & 47.51 & 44.72 \\
\hline \multirow{2}{*}{$\begin{array}{l}\text { Total costs of UAA } \\
\text { (EUR thousand/ha) }\end{array}$} & A & 0.66 & 1.42 & 0.67 & 1.36 & 0.85 & 1.37 & 1.12 & 1.45 \\
\hline & B & 1.01 & 1.57 & 0.93 & 1.62 & 1.09 & 2.03 & 1.64 & 2.57 \\
\hline \multirow{2}{*}{$\begin{array}{l}\text { Direct costs of UAA } \\
\text { (EUR thous./ha) }\end{array}$} & A & 0.27 & 0.41 & 0.34 & 0.44 & 0.38 & 0.50 & 0.38 & 0.66 \\
\hline & B & 0.45 & 0.39 & 0.45 & 0.47 & 0.47 & 0.67 & 0.47 & 0.88 \\
\hline \multirow{2}{*}{$\begin{array}{l}\text { Costs of external inputs } \\
\text { (EUR thous./ha) }\end{array}$} & A & 0.05 & 0.15 & 0.06 & 0.19 & 0.15 & 0.26 & 0.27 & 0.44 \\
\hline & B & 0.11 & 0.19 & 0.10 & 0.26 & 0.14 & 0.37 & 0.39 & 0.73 \\
\hline \multirow{2}{*}{$\begin{array}{l}\text { Share of subsidies in farm income } \\
(\%)\end{array}$} & A & 57.20 & 182.64 & 54.63 & 106.00 & 62.61 & 99.15 & 82.36 & 145.09 \\
\hline & B & 47.78 & 94.71 & 50.03 & 74.39 & 45.64 & 54.71 & 332.67 & 77.96 \\
\hline
\end{tabular}

Source: own study based on FADN data.

except for very large type B Polish farms where it amounted to $332 \%$ (compared to $78 \%$ in German farms).

\section{COMPETITIVENESS OF POLISH AND GERMAN FARMS IN 2014-2016}

The analysis revealed a deterioration in farm competitiveness between 2014-2016 and the previous period. This is evidenced by the figures shown in Tables 6 and 7 . All type A farms, except for large Polish farms, recorded a negative entrepreneur's profit and a Competitiveness Index below 1. Thus, they did not demonstrate a competitive capacity. Polish large farms exhibited their competitive capacity by reaching a $\mathrm{Wk}_{3}$ index of 1.21 . In type $\mathrm{B}$, competitive capacity was not demonstrated by Polish medium-small farms and German farms (except for very large farms). Competitive capacity was found in medium-large and large type B Polish farms and in very large German farms, with a $\mathrm{Wk}_{3}$ index of $1.17,1.39$ and 1.55 , respectively. Full competitive capacity was exhibited only by very large Polish farms with a $\mathrm{Wk}_{4}$ index of 2.20 .

When comparing Polish and German farms specializing in field crops in 2014-2016, it can be concluded that Polish farms:

- had higher farm incomes in both types, except for very large type A farms where it was lower than in German farms,

- incurred lower costs of own productive inputs, except for large type A farms and very large type B farms,

- had a larger UAA, except for medium-large type B farms, 
Zieliński, M., Ziętara, W. (2019). Competitiveness of Polish and German farms specialized in field crops. J. Agribus. Rural Dev., 3(53), 281-290. http://dx.doi.org/10.17306/J.JARD.2019.01261

Table 6. Selected variables describing the competitive capacity of Polish and German farms specializing in the cultivation of cereals, oilseeds and protein crops for seeds (type A) and in the cultivation of various crops (type B), grouped by economic size (SO) in 2014-2016

\begin{tabular}{|c|c|c|c|c|c|c|c|c|c|}
\hline \multirow{3}{*}{ Specification } & \multirow{3}{*}{$\begin{array}{l}\text { Farm } \\
\text { type }\end{array}$} & \multicolumn{8}{|c|}{ Farms by SO (EUR thous.) } \\
\hline & & \multicolumn{2}{|c|}{$25-50$} & \multicolumn{2}{|c|}{$50-100$} & \multicolumn{2}{|c|}{$100-500$} & \multicolumn{2}{|c|}{$\geq 500$} \\
\hline & & Poland & Germany & Poland & Germany & Poland & Germany & Poland & Germany \\
\hline \multirow{2}{*}{$\begin{array}{l}\text { Farm income } \\
\text { (EUR thous./farm) }\end{array}$} & A & 13.64 & 5.64 & 28.33 & 13.91 & 73.22 & 51.95 & 38.13 & 117.87 \\
\hline & B & 14.74 & 13.07 & 27.98 & 18.53 & 61.42 & 57.98 & 238.11 & 135.61 \\
\hline \multirow{2}{*}{$\begin{array}{l}\text { Costs of own productive inputs } \\
\text { (EUR thous./farm) }\end{array}$} & A & 18.96 & 21.20 & 28.80 & 30.67 & 60.90 & 54.16 & 122.90 & 123.02 \\
\hline & $\mathrm{B}$ & 16.24 & 21.87 & 23.88 & 32.77 & 44.19 & 60.52 & 107.81 & 87.29 \\
\hline \multirow{2}{*}{$\begin{array}{l}\text { Entrepreneur's profit } \\
\text { EUR thous./farm }\end{array}$} & A & -5.32 & -15.56 & -0.47 & -16.76 & 12.32 & -2.21 & -84.77 & -5.15 \\
\hline & B & -1.50 & -8.80 & 4.10 & -14.24 & 17.23 & -2.54 & 130.30 & 48.32 \\
\hline \multirow{2}{*}{$\begin{array}{l}\text { Competitiveness Index } \\
\text { (ratio) }\end{array}$} & A & 0.71 & 0.27 & 0.98 & 0.45 & 1.21 & 0.95 & 0.31 & 0.96 \\
\hline & B & 0.91 & 0.59 & 1.17 & 0.56 & 1.39 & 0.94 & 2.20 & 1.55 \\
\hline \multirow{2}{*}{$\begin{array}{l}\text { Net investment rate } \\
(\%)\end{array}$} & A & -9.85 & 36.75 & 31.09 & 6.80 & 20.66 & 34.79 & -3.77 & 80.82 \\
\hline & B & -6.48 & -34.86 & 24.49 & 9.89 & 125.68 & 37.59 & 118.02 & 55.03 \\
\hline
\end{tabular}

Source: own study based on FADN data.

Table 7. Selected variables of Polish and German farms specializing in the cultivation of cereals, oilseeds and protein crops for seeds (type A) and in the cultivation of various crops (type B), grouped by economic size (SO) in 2014-2016

\begin{tabular}{|c|c|c|c|c|c|c|c|c|c|}
\hline \multirow{3}{*}{ Specification } & \multirow{3}{*}{$\begin{array}{l}\text { Farm } \\
\text { type }\end{array}$} & \multicolumn{8}{|c|}{ Farms by SO (EUR thous.) } \\
\hline & & \multicolumn{2}{|c|}{$25-50$} & \multicolumn{2}{|c|}{$50-100$} & \multicolumn{2}{|c|}{$100-500$} & \multicolumn{2}{|c|}{$\geq 500$} \\
\hline & & Poland & Germany & Poland & Germany & Poland & Germany & Poland & Germany \\
\hline \multirow[t]{2}{*}{ Utilized agricultural area (ha) } & $\mathrm{A}$ & 42.40 & 34.60 & 80.00 & 63.50 & 224.80 & 174.40 & $1,026.40$ & 869.70 \\
\hline & $\mathrm{B}$ & 26.90 & 34.50 & 49.80 & 54.80 & 121.80 & 99.30 & 710.90 & 345.60 \\
\hline \multirow{2}{*}{$\begin{array}{l}\text { Value of assets per hectare of } \\
\text { UAA (EUR thous./ha) }\end{array}$} & A & 7.30 & 13.30 & 6.90 & 11.10 & 5.60 & 6.80 & 3.00 & 4.60 \\
\hline & $\mathrm{B}$ & 8.40 & 14.20 & 8.40 & 13.60 & 7.90 & 12.60 & 4.20 & 7.70 \\
\hline \multirow{2}{*}{$\begin{array}{l}\text { Value of assets } \\
\text { (EUR thous./AWU) }\end{array}$} & A & 206.20 & 541.90 & 323.00 & 634.40 & 399.80 & 715.20 & 169.80 & 569.60 \\
\hline & B & 112.10 & 550.30 & 169.10 & 630.30 & 258.40 & 594.60 & 181.30 & 288.70 \\
\hline \multirow{2}{*}{$\begin{array}{l}\text { Share of cereals in UAA } \\
(\%)\end{array}$} & A & 67.5 & 63.3 & 65.2 & 63.2 & 64.60 & 61.8 & 64.4 & 58.8 \\
\hline & $\mathrm{B}$ & 50.8 & 40.8 & 48.8 & 44.2 & 47.8 & 47.2 & 42.7 & 43.2 \\
\hline \multirow{2}{*}{$\begin{array}{l}\text { Total costs of UAA } \\
\text { (EUR thous./ha) }\end{array}$} & A & 0.790 & 1.556 & 0.831 & 1.407 & 0.884 & 1.351 & 1.289 & 1.553 \\
\hline & $\mathrm{B}$ & 1.053 & 1.459 & 1.111 & 1.693 & 1.234 & 2.238 & 1.730 & 2.912 \\
\hline \multirow{2}{*}{$\begin{array}{l}\text { Direct costs of UAA } \\
\text { (EUR thous./ha) }\end{array}$} & A & 0.365 & 0.459 & 0.399 & 0.423 & 0.409 & 0.448 & 0.551 & 0.491 \\
\hline & B & 0.455 & 0.387 & 0.509 & 0.463 & 0.569 & 0.724 & 0.765 & 0.916 \\
\hline \multirow{2}{*}{$\begin{array}{l}\text { Costs of external inputs } \\
\text { (EUR thous./ha) }\end{array}$} & A & 0.050 & 0.199 & 0.063 & 0.185 & 0.128 & 0.267 & 0.332 & 0.506 \\
\hline & $\mathrm{B}$ & 0.98 & 0.183 & 0.122 & 0.274 & 0.163 & 0.461 & 0.408 & 0.934 \\
\hline \multirow{2}{*}{$\begin{array}{l}\text { Share of subsidies in farm } \\
\text { income }(\%)\end{array}$} & A & 86.90 & 242.74 & 76.26 & 173.56 & 72.81 & 117.22 & 104.06 & 315.10 \\
\hline & B & 59.79 & 118.34 & 55.20 & 118.84 & 58.10 & 64.60 & 94.80 & 92.05 \\
\hline
\end{tabular}

Source: own study based on FADN data. 
- had a lower value of assets per hectare of UAA and per AWU,

- had a less sustainable production organization, expressed by the share of cereals in UAA, except for very large type $\mathrm{B}$ farms where that share was slightly smaller,

- had a lower level of production intensity and lower costs of external productive inputs,

- had a lower share of subsidies in farm income; it varied in the range of $76.2 \%$ to $104 \%$ in Polish type A farms, and in the range of $117.2 \%$ to $315 \%$ in German farms; in type B farms, the share of subsidies in income was lower.

\section{SUMMARY AND CONCLUSIONS}

1. Agriculture of both countries experiences production specialization and concentration processes. They are reflected in a growing share of farms specialized in specific production types. In both countries, farms specializing in field crops play an important role. German and Polish farms operated more than 30\% and $50 \%$ of utilized agricultural area, respectively.

2. A significant problem was to determine the competitiveness of farms, defined as proposed by W. Kleinhanss, using a ratio of farm income to costs of own productive inputs. This method made it possible to identify various levels of competitiveness of farms (fully competitive; able to compete; and without competitive capacity) in the economic conditions of the country concerned. This method proved to be more precise than the one previously used by the authors which was based on the category of entrepreneur's profit. Owing to this approach, there is need neither to make direct comparisons between farms from various countries nor to determine their competitive advantages.

3. During the first two periods (2006-2008 and 20102012), Polish medium-small and medium-large type A and B farms exhibited their competitive capacity. This was not the case for corresponding German farms of both types. In the third period (2014-2016), none of the Polish and German medium-small farms demonstrated their competitive capacity. This was the result of a deteriorated relation between the costs of productive inputs and selling prices of agricultural products. Polish farms operated a larger utilized agricultural area.
4. In the first and third period, Polish medium-large farms demonstrated their competitive capacity whereas in the second period, they were fully competitive. In this economic size class, German farms did not have a competitive capacity, except for type $\mathrm{B}$ farms in the second period. In this class, Polish farms also operated a larger utilized agricultural area.

5. In the large farm class, Polish farms were fully competitive in the first two periods, except for type A farms in the first period. In the third period, they exhibited their competitive capacity. German farms in this class demonstrated their competitive capacity during the first and second period. Exceptions were type A farms in the first period (no competitive capacity) and type B farms in the second period (fully competitive). Polish farms operated a larger utilized agricultural area in all periods.

6. In the first period, Polish and German very large farms demonstrated their competitive capacity. Conversely, in the second period, Polish type B farms had a competitive capacity whereas Polish type A farms and German type A and type B farms were fully competitive. In the third period, Polish and German type A farms were uncompetitive, Polish type B farms were fully competitive, and German type B farms had a competitive capacity. In this class, too, Polish farms operated a larger utilized agricultural area.

7. Polish farms specializing in field crops, when compared to German farms, had higher farm incomes despite a lower value of assets per hectare and per AWU and a lower production intensity.

8. In both types of Polish and German farms, the main source of income were all types of subsidies allocated to farmers. The vast majority of Polish farms had a smaller share of subsidies in incomes.

\section{REFERENCES}

Biswanger, H. Ch. (2011). Spirala wzrostu. Pieniądz, energia i kreatywność w dynamice procesów rynkowych [The growth spiral: Money, energy, and imagination in the dynamics of the market process]. Poznań: Zysk i S-ka [in Polish].

Brinkmann, T. (1922). Die oekonomik des landwitschaftlichen Betriebes. Grundriss der Sozialoekonomik. Tübingen. 
CSO (2015). Statistical Yearbook of Agriculture 2014. Warsaw: Central Statistical Office.

CSO (2018). Characteristics of farms 2016. Warsaw: Central Statistical Office.

Gallardo, R., Ramos, F., Ramos, E. (2001). The farm strategy approach towards competitiveness under the CAP Reforms. The Case of Andalusia in Southern Spain. European Association of Agricultural Economists Congress, 2001.

Kleinhanss, W. (2015). Competitiveness of major types of farms in Germany. Probl. Agric. Econ., 1, 24-39.

Płonka, R. (2015). Competitiveness of farms of natural persons who have uninterruptedly kep agricultural accounting under Polish FADN in the years 2005-2013, a conference on: Income situation of farms in 2013 based on agricultural accounting of Polish FADN and current analysis of the agricultural sector, 14.09.2015, Pomorski Agricultural Advisory Centre, Gdańsk.

Sass, R. (2017). Efektywność i konkurencyjność gospodarstw mlecznych w regionie Wielkopolski i Śląska w zależności od skali produkcji [Effectiveness and competitiveness of dairy farms in the regions of Wielkopolska and Śląsk depending on the production scale]. Zagad. Dor. Roln., 3(89), 5-19 [in Polish].

Statistisches Jahrbuch über Ernährung, Landwirtschaft und Forsten 2014 (2015). Münster: Landwirtschaftsverlag.

Statistisches Jahrbuch über Ernährung, Landwirtschaft und Forsten 2017 (2018). Münster: Landwirtschaftsverlag.

Ziętara, W., Zieliński, M. (2012). Efektywność i konkurencyjność polskich gospodarstw rolniczych nastawionych na produkcję roślinną [Effectiveness and competitiveness of farms oriented towards the crop production]. Zagad. Ekon. Roln., 1, 40-61 [in Polish].

Ziętara, W., Zieliński, M. (2015). Organizacja i efektywność polskich gospodarstw specjalizujących się w uprawach polowych na tle gospodarstw wybranych krajów [Organisation and effectiveness of Polish farms specialised in field crops against a background of farms in selected countries]. In: W. Józwiak (Ed.) Przedsiębiorstwo i gospodarstwo rolne wobec zmian klimatu i polityki rolnej [Enterprise and farm in relation to climate change and agricultural policies]. Warsaw: IERiGŻ-PIB [in Polish]. 